\title{
High Sensitivity PEA System with Dual Polarity Pulse Generator
}

\author{
Kouhei Matsui Student Member (Musashi Institute of Technology, kouhei@nict.go.jp) \\ Yasuhiro Tanaka Member (Musashi Institute of Technology, tanaka@me.musashi-tech.me.jp) \\ TatsuoTakada Member (Musashi Institute of Technology, takada@me.musashi-tech.ac.jp) \\ Tadashi Fukao Member (Musashi Institute of Technology, tfukao@me.musashi-tech.ac.jp) \\ Takashi Maeno Member (National institute of information and communications technology, tmaeno@nict.go.jp)
}

Keywords : high sensitivity, space charge, pulsed electroacoustic method, Maxwell stress

The PEA method has been widely used to observe space charge distributions in various solid dielectric materials. The sensitivity of the conventional PEA system is around $1 \mathrm{C} / \mathrm{m}^{3}$. When the charge density is less than $1 \mathrm{C} / \mathrm{m}^{3}$, however, it is difficult to obtain an accurate result because the signal due to the Maxwell stress becomes comparable with the signal to be measured. The Maxwell stress is generated by applying the pulsed electric field to the dielectrics, and independent from the existence of either induced charges by dc bias voltage or internal charges. In order to eliminate the influence of the Maxwell stress, we have developed a new PEA system with a dual polarity pulse generator. The system achieved to measure space charge density around 0.03 $\mathrm{C} / \mathrm{m}^{3}$.

When a dc voltage is applied to a specimen, surface charges are induced on both electrodes. In the PEA method, the pressure wave generated at the interface between the electrode and the specimen $p(0, t)$ is described as;

$$
p(0, t)=C \times\left(\varepsilon_{0} \varepsilon_{r} \sigma_{1} e_{p}(t)+\frac{1}{2} \varepsilon_{0} \varepsilon_{r} e_{p}(t)^{2}\right)
$$

Where $\mathrm{C}$ is a constant determined by the acoustic property of the material, $\varepsilon_{\mathrm{r}}$ the relative permittivity, $\sigma_{1}$ the induced charge at the interface of electrode and $e_{p}(t)$ is the applied pulse voltage. First term means the pressure wave related with induced charge and second term means that of the Maxwell stress.

The signal due to Maxwell stress is usually small enough to ignore the influence on the ourput signal generated by the induced charges. However, when the charge density is less than $0.1 \mathrm{C} / \mathrm{m}^{3}$ or when the applied pulse voltage is large, the signal due to Maxwell stress affects the measurement.

In order to eliminate the influence of the Maxwell stress, we developed a new dual pulse generator. The new pulse generator supplies both positive and negative pulse voltages. When the negative pulse voltage is applied, Eq. (1) becomes;

$$
p^{-}(0, t)=C \times\left(-\varepsilon_{0} \varepsilon_{r} \sigma_{1} e_{p}(t)+\frac{1}{2} \varepsilon_{0} \varepsilon_{r} e_{p}(t)^{2}\right) \cdots
$$

And then, by subtracting (2) from (1), the second term, i.e. the signal due to Maxwell stress is removed, as shown in Eq. (3).

$$
p^{\prime}(0, t)=C \times \varepsilon_{0} \varepsilon_{r} \sigma_{1} e_{p}(t)
$$

Figure 1 shows the measurement results by using the new high sensitivity PEA system. Polyethylene naphthalate (thickness: 0.2 $\mathrm{mm}$ ) was used as a specimen and a dc bias voltage of 10 to $50 \mathrm{~V}$ were applied. As shown in this figure, the new PEA system can measure the space charge at the sensitivity of $0.03 \mathrm{C} / \mathrm{m}^{3}$ or higher.

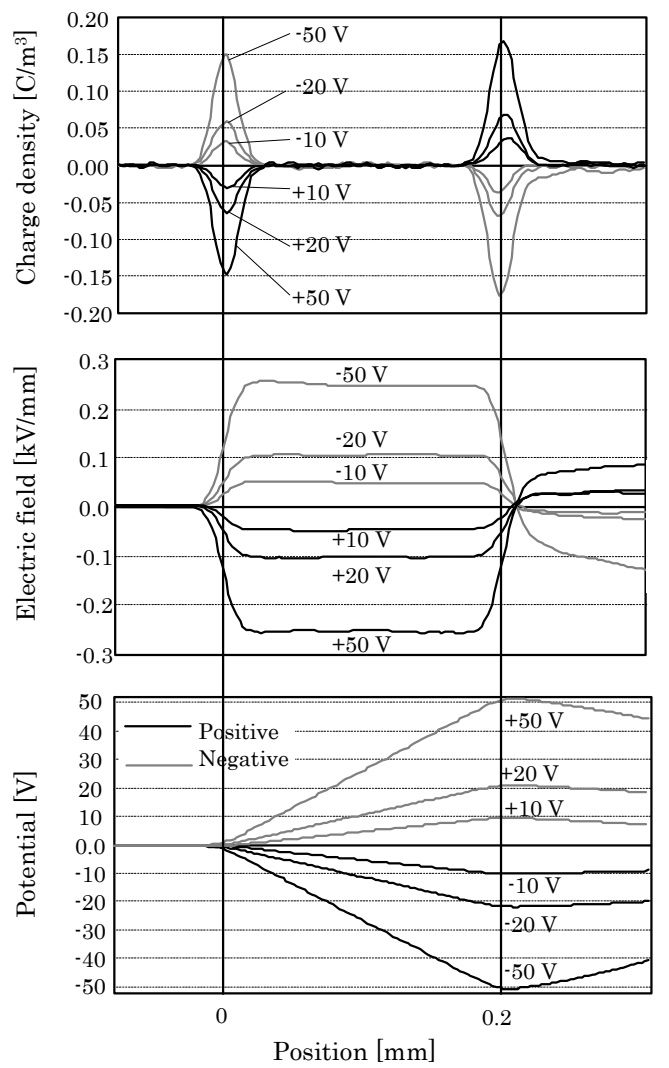

Fig. 1. Charge, electric field disributions in dc biased $0.2 \mathrm{~mm}$-thick PEN; Baias voltage 50, 20, 10V 


\title{
正負パルス電圧を用いた高感度 PEA 装置
}

$\begin{array}{cccccc}\text { 学生員 松井 } & \text { 康平* } & \text { 正員 } & \text { 田中 } & \text { 康寛* } \\ \text { 正員 高田 } & \text { 達雄* } & \text { 正員 } & \text { 深尾 } & \text { 正 } \\ \text { 正 員 前野 } & \text { 恭** } & & & & \end{array}$

\author{
High Sensitivity PEA System with Dual Polarity Pulse Generator \\ Kohei Matsui*, Sutudent Member, Yasuhiro Tanaka*, Member, Tatsuo Takada*, Member, \\ Tadashi Fukao*, Member, Takashi Maeno**, Member
}

\begin{abstract}
The pulsed electroacoustic (PEA) method has been widely used to observe space charge distributions in various solid dielectric materials. The sensitivity of the conventional PEA system is around $1 \mathrm{C} / \mathrm{m}^{3}$. When the charge density is less than $1 \mathrm{C} / \mathrm{m}^{3}$, however, it is difficult to obtain an accurate result because the signal due to the Maxwell stress becomes comparable with the signal to be measured. The Maxwell stress is generated by applying the pulsed electric field to the dielectrics, and independent from the existence of either induced charges by dc bias voltage or internal charges. In order to eliminate the influence of the Maxwell stress, we have developed a new PEA system with a dual polarity pulse generator. The system achieved to measure space charge density around $0.03 \mathrm{C} / \mathrm{m}^{3}$.
\end{abstract}

キーワード : 高感度, パルス静電応力法, 空間電荷, マックスウェル応力

Keywords : high sensitivity, pulsed electroacoustic technique, space charge, Maxwell stress

\section{1. はじめに}

パルス静電応力法 (Pulsed electroacostic technique, 以 下 PEA 法) は，固体誘電体中の空間電荷計測に広く使われ おり，ポリエチレンなどの高分子試料において， $1 \mathrm{C} / \mathrm{m}^{3}$ 程 度の空間電荷密度が容易に測定できる感度のよい測定法で ある(1) (4)。PEA 法では電荷測定を行うためにパルス電界を 試料に印加する必要があるが, 印加時に試料内部の空間電 荷に生じるクーロン力とは別に, 電極 - 試料界面に電極と 試料の誘電率の違いに起因するマックスウェル応力が発生 する。このマックスウェル応力は試料 - 電極界面や試料内 部に電荷がない場合でも発生し，印加パルス電界の大きさ の 2 乗に比例する。そのため, $0.1 \mathrm{C} / \mathrm{m}^{3}$ 程度の小さな電荷量 を測定する場合や，感度を上げるために大きなパルス電界 を印加した場合は，相対的にマックスウェル応力により生 じる圧力波が大きくなり, 測定誤差増加の要因となる。こ の圧力波形はあらかじめ測定しておき, 実験結果から差し

\footnotetext{
* 武蔵工業大学

年158-5587 東京都世田谷区玉堤 1-28-1

Musashi Institute of Technology

1-28-1, Tamazutsumi, Setagaya-ku, Tokyo 158-5587

** 情報通信研究機構

T184-8795 小金井市貫井北町 4-2-1

National Institute of Information and Communications technology

4-2-1, Nukuikitamachi, Koganei 184-8795
}

引くことで誤差を低減することが可能であり, 従来の測定 では電荷量が小さい場合にはこのような方法で対処してき た。しかしながら, 実験が長時間に及ぶ連続測定の場合, 温度変化などによる PEA 装置のわずかな特性変化のため圧 力波形も変化し，十分除去することができなくなる。また， こうした経時変化による波形の摇らぎは時間を経るにした がって大きくなり, 残差も増加する。そこで, 短時間間隔 でこの圧力波の影響を差し引くことを目的として, 正負の パルス電圧を交互に印加する PEA 装置を開発した。本方式 により, 従来より一桁小さい $0.01 \mathrm{C} / \mathrm{m}^{3}$ オーダーでの電荷分 布測定が可能な高感度 PEA 装置が実現できた。

\section{PEA 法の測定下限界}

通常 PEA 法では, 圧電素子からの出力信号の信号対雑音 比（以下 $\mathrm{SN}$ 比）を向上させるため, デジタルオシロスコー プにて同期加算平均（アベレージング）処理が行われる。 同期加算平均処理により, ワンショットでは雑音に埋もれ てしまう微小な電荷量も測定することが可能である。図 1 に厚さ $0.2 \mathrm{~mm}$ のポリエチレンナフタレート $(\mathrm{PEN})$ にパル ス電圧 $100 \mathrm{~V}$, 印加電圧 $500 \mathrm{~V}$ における, 圧電素子からの出 力信号と信号処理 ${ }^{(5)}$ を行った電荷分布, 電荷分布から計算さ れる電界, 電位分布を示す。図 1 において左から同期加算 


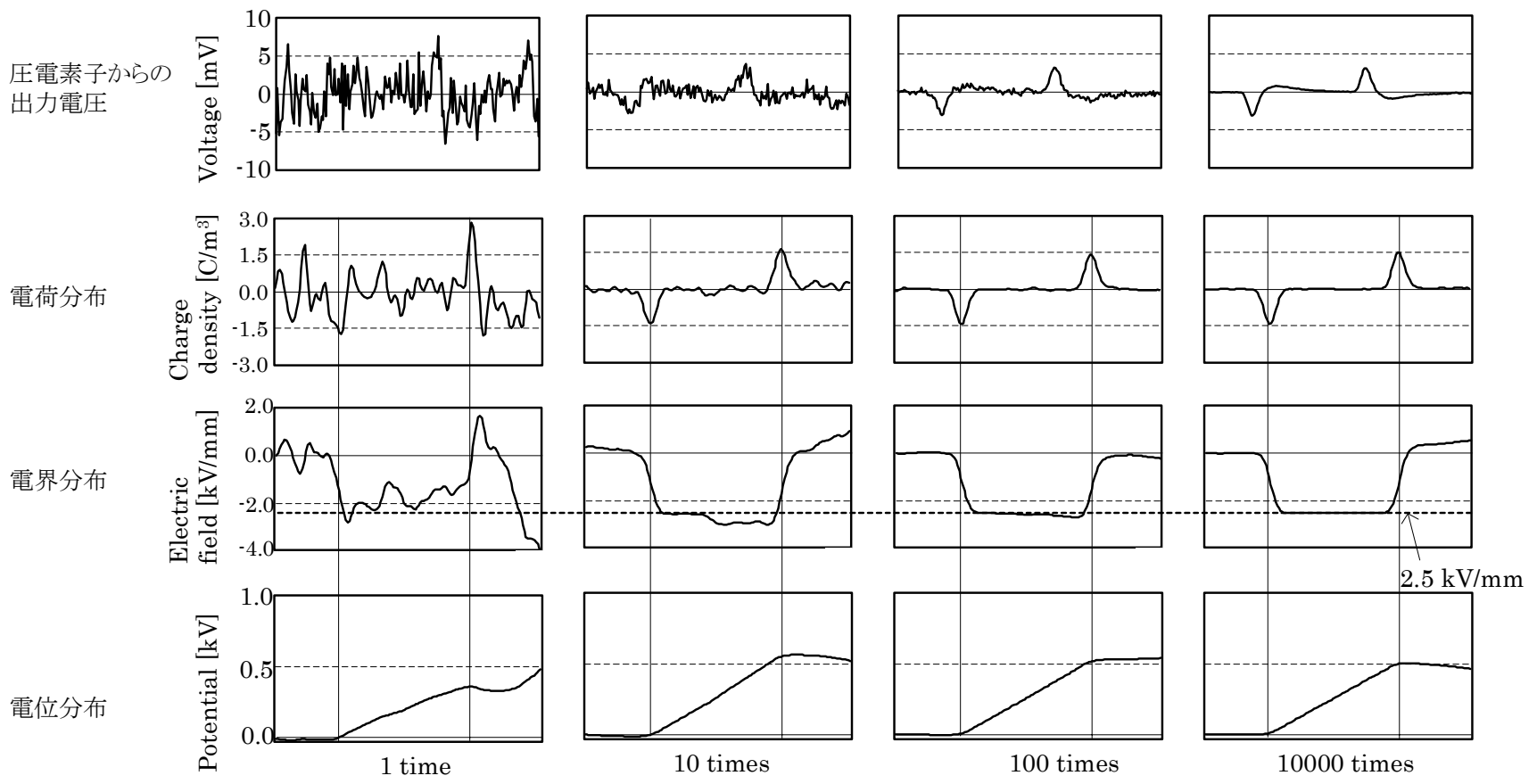

図 1 PEA 法を用いた空間電荷分布測定における同期加算平均の効果（PEN0.2mm，印加電圧 $500 \mathrm{~V}$, 印加電界 $2.5 \mathrm{kV} / \mathrm{mm}$ )

Fig. 1. Effect of averaging technique on space charge measurement by using PEA method (0.2mm- thick PEN, applied voltage $500 \mathrm{~V}$, applied electric $2.5 \mathrm{kV} / \mathrm{mm}$ ).

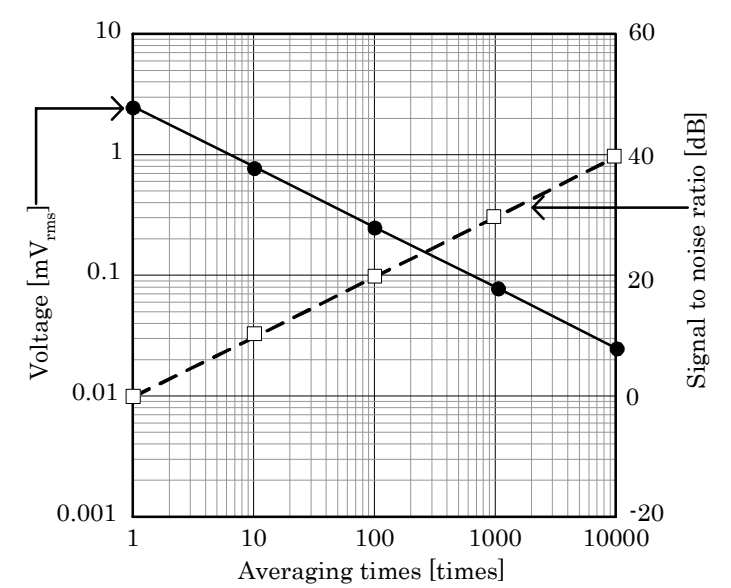

図 2 同期加算平均数と白色雑音の実効值の関係

Fig. 2. Relationship between averaging time and the root mean square of white noise.

平均回数 $1 ， 10 ， 100 ， 10000$ 回の結果を示している。同期 加算平均数が増加するにつれて, 雑音成分が減少する様子 がわかる。この白色雑音は平均回数の $1 / 2$ 乗に比例して, 減 少することが知られている(6)。図 2 に同期加算平均数と雑音 の実効值の関係を示す。また, 下部電極側の信号（信号波 形で最初に現れるパルス。図 1 最上段の各波形で左側, 負 のパルスを示す) のピーク值に対する SN 比も示す。両対数 グラフにおいて雑音成分は傾き $-1 / 2$ で減少していく。ま た，信号成分は同期加算平均回数を増やしても，変化しな いので, SN 比は雑音成分の低下に比例して, 傾き $1 / 2$ で増 加していく。図 3 には同期加算平均回数と電荷分布の雑音

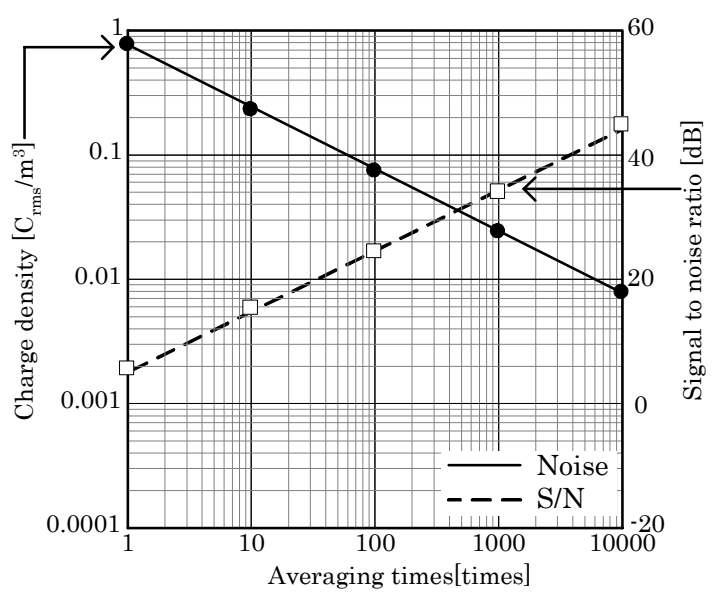

図 3 同期加算平均数と信号処理後の空間電荷分布 における雑音の実効值の関係

Fig. 3. Relationship between averaging time and the root mean square of noise on a space charge distribution after the signal processing.

成分の実効值と SN 比の関係を示す。電荷分布においても, 傾き $-1 / 2$ で雑音が減少していることがわかる。図 3 から PEA 法の測定下限界を求めると
One shot
$0.77 \mathrm{C}_{\mathrm{rms}} / \mathrm{m}^{3}$
同期加算平均適用後
100 回
$0.074 \mathrm{C}_{\mathrm{rms}} / \mathrm{m}^{3}$
10000 回
$0.0078 \mathrm{C}_{\mathrm{rms}} / \mathrm{m}^{3}$

となる。ここで，測定下限界はオシロスコープで測定され る白色雑音の大きさとセンサーの感度によって決定され 
る。オシロスコープで測定される白色雑音の大きさは増幅 器の雑音指数 (noise figure) と帯域幅およびオシロスコー プの帯域幅によって決定される。そのため, 測定下限界は システム固有の值であり, 常に一定であると考えることが できる。本装置で用いている増幅器は Miteq 社製, 帯域 $500 \mathrm{MHz}$ ，増幅率 $45 \mathrm{~dB}$ (AU-1332)，デジタルオシロスコ ープは LeCroy 社製, 帯域 $1 \mathrm{GHz}$ (LC584AM）である。た だし，信号処理時に使用する分解能を決めるガウスフィル ターのカットオフ周波数で, 雑音成分の大きさは異なる(2)。 本論文では，分解能は $16 \mu \mathrm{m}$ で固定した状態で全ての実験 を行った。ここで, 測定下限界と SN 比を対応させ, 図 1 からも判断すると測定下限界から $20 \mathrm{~dB}$ 程度の信号成分が あれば，測定した電荷量を $1 ， 2$ 階積分した電界，電位が印 加電界, 印加電圧と誤差 $10 \%$ 以内で一致する。このことか ら，電荷量を誤差 $10 \%$ 以内で測定していると判断できる。 図 4 に $0.2 \mathrm{~mm}$ 厚の $\mathrm{PEN}$, パルス電圧 $400 \mathrm{~V}$, 印加電圧土 500 , $250,100 \mathrm{~V}$, 同期加算平均数 5000 回の結果を示す。印加電 圧土500V では，測定した電荷量を $1 ， 2$ 階積分した電界， 電位が印加電界，電圧に誤差 $10 \%$ 以内で一致している。し かし，+250, 100Vでは，電荷量から算出された電界，電位

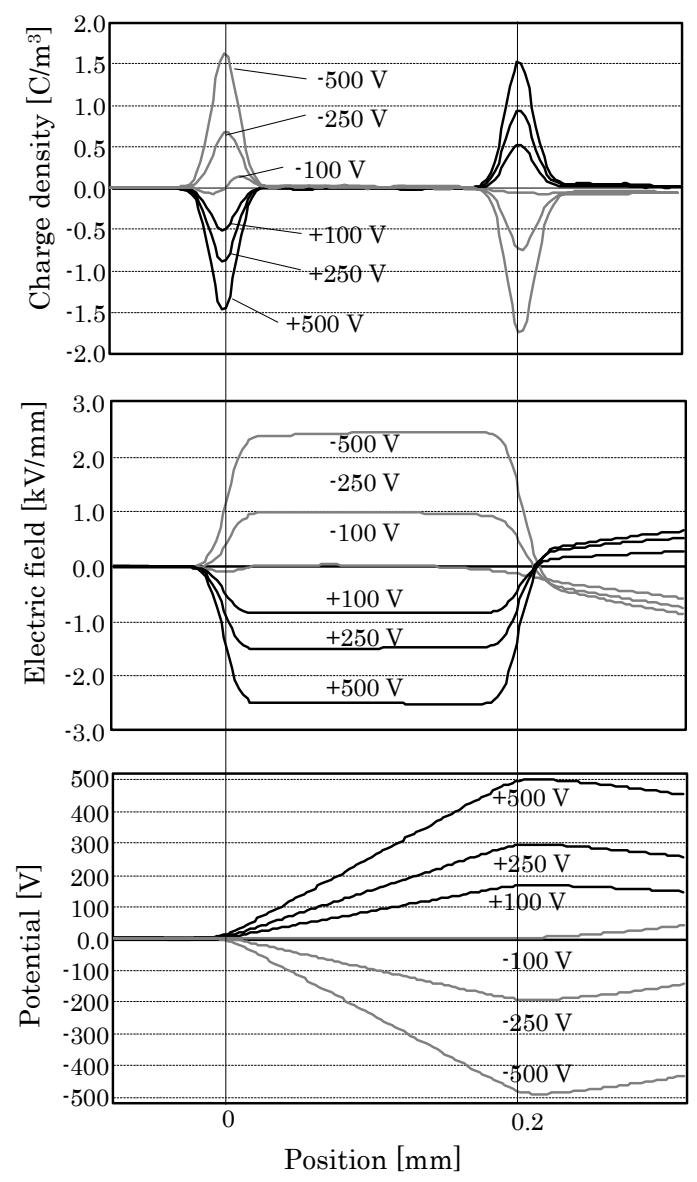

図 4 厚さ $0.2 \mathrm{~mm}$ PEN の電荷, 電界, 電位分布

Fig. 4. Space charge, electric field and potential distributions in $0.2 \mathrm{~mm}$-thick PEN.
が 10\%以上大きく，- $250 \mathrm{~V}$ では逆に $10 \%$ 以上小さくなり， $-100 \mathrm{~V}$ では界面に誘導されるはずの電荷を観測できない 結果となってしまう。同期加算平均数 5000 回では図 3 から 分かるように測定下限界が $0.01 \mathrm{C}_{\mathrm{rms}} / \mathrm{m}^{3}$ 程度であるので, $\pm 250,100 \mathrm{~V}$ の印加電圧で発生する電荷量 $\left( \pm 0.1 \mathrm{C} / \mathrm{m}^{3}\right.$ の才 ーダー) より十分小さいが，誤差が $10 \%$ 以上となってしま う。この理由としてパルス電圧によって発生するマックス ウェル応力が挙げられる。マックスウェル応力により生じ る誤差は系統誤差であり, 同期加算平均数をこれ以上増加 させても改善しない。これを説明するために PEA 法の原理 について簡単に述べる。

\section{PEA 法の原理とマックスウェル応カ}

PEA 法の原理図と得られる信号波形の例を図 5 に示す ${ }^{(5)}$ 。 ここで示すように, 試料内部の位置 $X_{p}$ にシート状電荷 $\sigma_{2}$ を 持つ板状試料を 2 つの電極で挟む。このとき両電極界面に は $\sigma_{1}, \sigma_{3}$ の誘導電荷が発生する。これに非常に狭いパルス電 圧を印加すると, 両電極界面にパルス状のマックスウェル 応力が発生する。左側接地電極と試料の界面に働く忘力を $f(0, t)$ とすると,

$$
\begin{aligned}
f(0, t) & =\frac{1}{2} \varepsilon_{0} \varepsilon_{r}\left(E(0)+e_{p}(t)\right)^{2} \\
& =\frac{1}{2} \varepsilon_{0} \varepsilon_{r} E(0)^{2}+\varepsilon_{0} \varepsilon_{r} E(0) e_{p}(t)+\frac{1}{2} \varepsilon_{0} \varepsilon_{r} e_{p}(t)^{2}
\end{aligned}
$$

ここで $e_{p}(t)=V_{p}(t) / d, \quad V_{p}(t)$ はパルス電圧, $d$ 試料厚, $\varepsilon_{r}$ は試料の比誘電率。

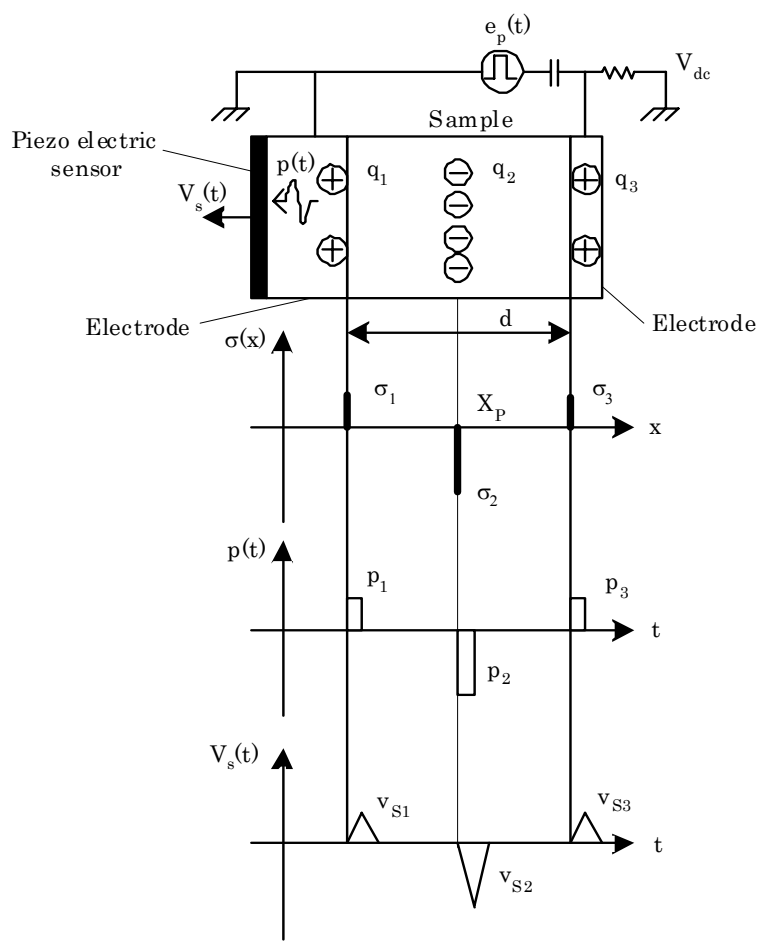

図 5 パルス静電応力法の原理

Fig. 5. Principal of pulsed electroacoustic method. 
となる。また，このとき発生する圧力波 $p_{1}$ は

$$
p_{1}(0, t)=C \times\left(\varepsilon_{0} \varepsilon_{r} E(0) e_{p}(t)+\frac{1}{2} \varepsilon_{0} \varepsilon_{r} e_{p}(t)^{2}\right)
$$

ただし，Cは試料の音響的性質によって決まる定数。 となり, 圧力波 $p_{1}$ は接地電極界面の電界強度 $E(0)$ に比例し た第 1 項と, パルス電界の 2 乗に比例した第 2 項との和に なる。右側電極界面で発生する圧力波 $p_{3}$ も同様である。こ のうち第 1 項が本来測定したい信号成分であり，第 2 項は オフセット成分に相当する装置の系統誤差となる。

一方, 試料内部の位置 $X_{p}$ にあるシート状電荷 $\sigma_{2}$ に働く力 $f(X p, t)$ はクーロン力であり, 働く力と得られる圧力波 $p_{2}$ は

$$
\begin{aligned}
& f\left(X_{p}, t\right)=\sigma_{2} \times e_{p}(t) \ldots \ldots . . \\
& p_{2}\left(X_{p}, t\right)=C \times \sigma_{2} \times e_{p}(t)
\end{aligned}
$$

となり，Vs2 のように検出され，信号の伝ぱん時間が位置を 表し大きさが密度を表す。

ここで界面電界強度に比例する $V_{s 1}$, と内部の電荷密度に 比例する信号 $V_{s 2}$ を比較する。この試料のような平行平板誘 電体においては, 界面電界強度 $E(0)$ と界面誘導電荷 $\sigma_{1}$ は次 の関係がある。

$$
E(0)=\frac{\sigma_{1}}{\varepsilon_{0} \varepsilon_{r}}
$$

従って (2)式は次のように書き換えることができる。

$$
p_{1}(0, t)=C \times\left(\sigma_{1} e_{p}(t)+\frac{1}{2} \varepsilon_{0} \varepsilon_{r} e_{p}(t)^{2}\right) .
$$

通常の測定では，(6)式において，パルス電界 $e_{p}(t)$ は誘導電 荷 $\sigma_{1}$ により発生する電界 $E(0)$ より十分小さい值を選ぶこ とにより，第 2 項は無視することができ，界面電荷，空間 電荷共に共通の式で扱うことができる(5)。

(4)式からも明らかなようにパルス電界を大きくすれば, それだけ大きな圧力波が発生し,微小な電荷を SN の良い条 件で測定することが可能となる。しかし，両電極界面では

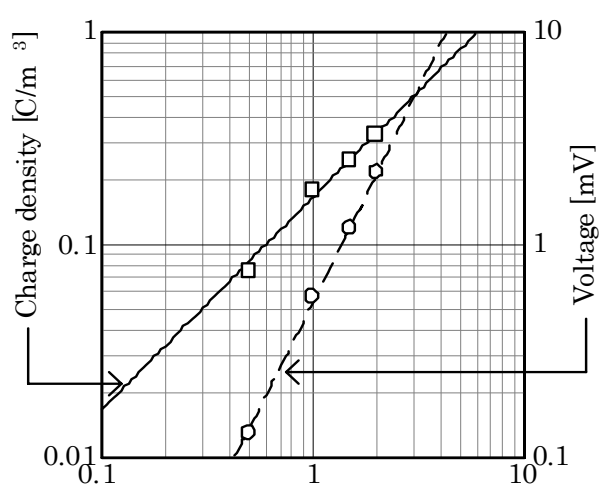

Pulse electric field $[\mathrm{kV} / \mathrm{mm}]$

図 6 パルス電界のみによって電極界面に発生する 電圧信号と電荷量のピーク值

Fig. 6. Peak values of voltage signals and charge quantity generated by only pulse electric field.
(6)式の第 2 項が無視できない大きさとなる。図 6 に，厚さ $0.2 \mathrm{~mm}$ の PEN にパルス電圧のみを印加した時の電極界面 での信号波形のピーク值と, これから計算される電荷密度 を示す。パルス電圧は $100,200,300,400 \mathrm{~V}$ (パルス電界と して $0.5,1.0,1.5,2.0 \mathrm{kV} / \mathrm{mm})$ である。信号波形のピーク值 は(6)式の第 2 項から予想されるように, 傾き 2 で増加しパ ルス電界の 2 乗に比例している。また, 電荷密度に換算す ると約 $0.1 \sim 0.3 \mathrm{C} / \mathrm{m}^{3}$ となり，これが誤差を $10 \%$ 以上にして いる原因である。

\section{4. マックスウェル応カを除去した高感度 PEA 装置}

正負パルス電圧を用い，演算によりマックスウェル応力 により生じる誤差を除去する方法について述べる。（6)式に おいて正パルス電圧を印加したときの左側電極の圧力波を $p^{+}(0, t)$, 負パルス電圧を $p^{-}(0, t)$ とすると,

$$
\begin{aligned}
& p^{+}(0, t)=C \times\left(\sigma_{1} e_{p}(t)+\frac{1}{2} \varepsilon_{0} \varepsilon_{r} e_{p}(t)^{2}\right) \\
& p^{-}(0, t)=C \times\left(\sigma_{1}\left(-e_{p}(t)\right)+\frac{1}{2} \varepsilon_{0} \varepsilon_{r}\left(-e_{p}(t)\right)^{2}\right) \\
& =C \times\left(-\sigma_{1} e_{p}(t)+\frac{1}{2} \varepsilon_{0} \varepsilon_{r} e_{p}(t)^{2}\right) .
\end{aligned}
$$

となる。ここで両者の差 $p^{\prime}(0, t)$ を求めると

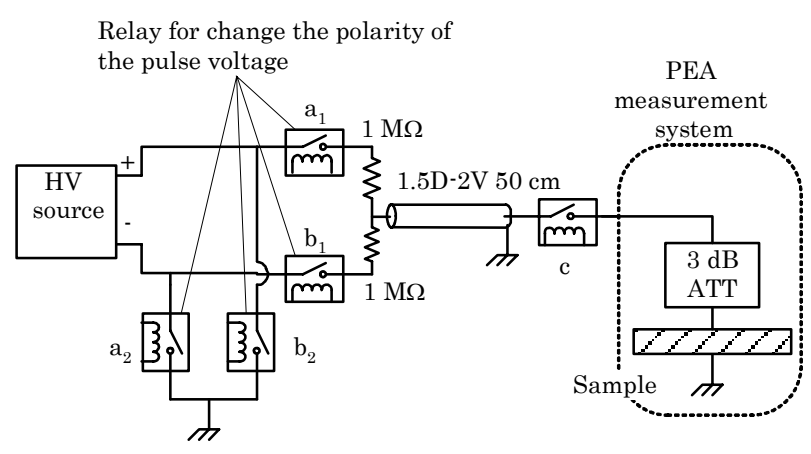

図 7 正負パルス電圧発生器

Fig. 7. Dual polarity pulse generator.

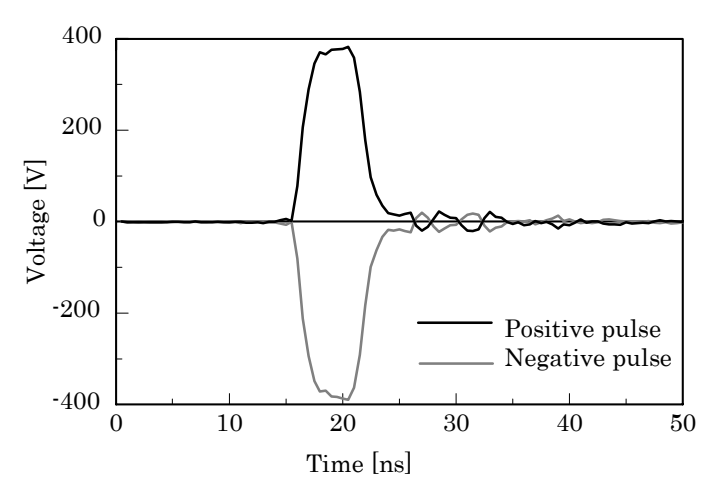

図 8 正負パルス電圧波形

Fig. 8. Positive and negative pulse voltage waveforms. 


$$
p^{\prime}(0, t)=p^{+}(0, t)-p^{-}(0, t)=C \times \sigma_{1} \times e_{p}(t)
$$

となり，マックスウェル応力による誤差，(6)式の第 2 項が 消去できる。同様に右側電極でも第 2 項成分を除去するこ とができる。また(9)式を繰り返すことにより同期加算平均 と同様に白色雑音の低減を行うことが可能である。

高感度 PEA 装置のために, 開発した正負パルス電圧発生 器を図 7 に示す。従来のラインパルサーからの変更点とし

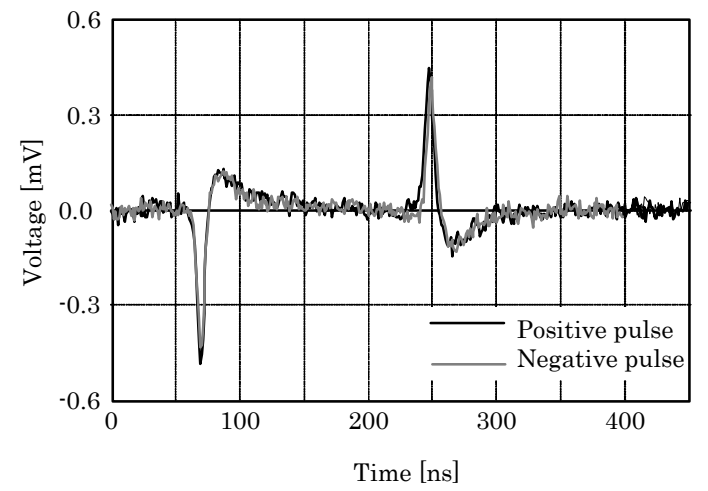

図 9 マスクウェル応力による出力信号

Fig. 9. Output signals by the Maxwell stress.

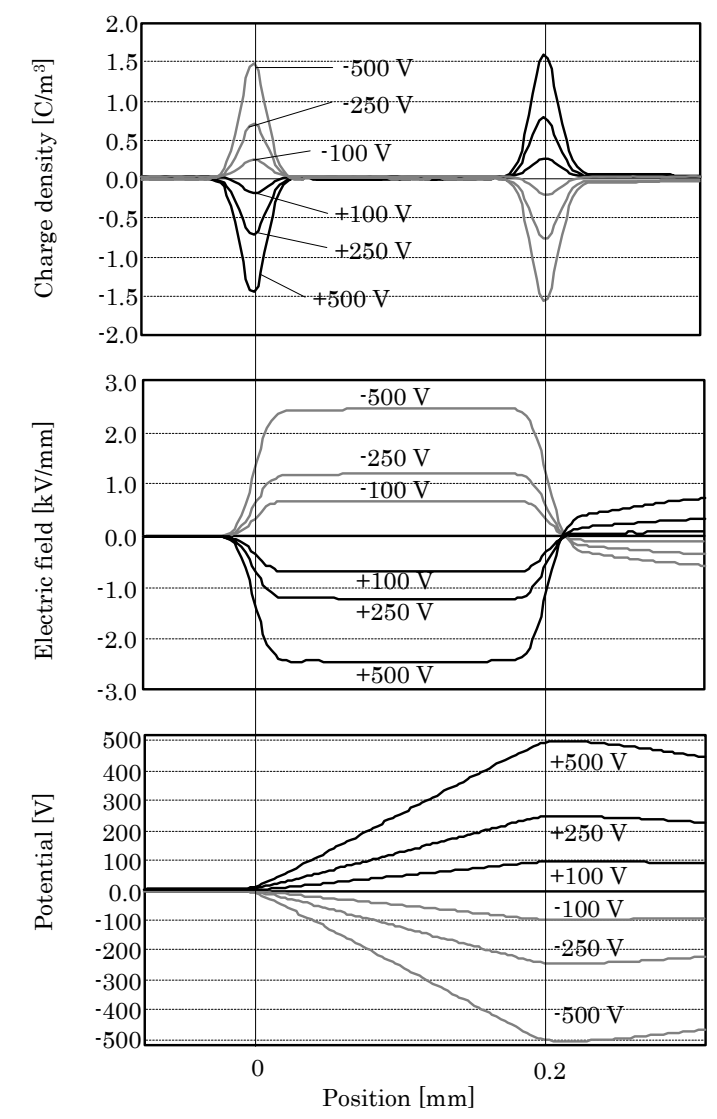

(a) Applied voltage : $\pm 500,250,100 \mathrm{~V}$
て, 直流電源から同軸ケーブルの間に 4 個のリレーを加え ることにより，同軸ケーブルに印加される電圧極性を切り 替えることができる。リレー $\mathrm{a}_{1}, \mathrm{a}_{2}$ を $\mathrm{ON}, \mathrm{b}_{1}, \mathrm{~b}_{2}$ を $\mathrm{OFF}$ とすると，正の電圧が同軸ケーブルの芯線に印加される。 逆に $\mathrm{b}_{1} ， \mathrm{~b}_{2}$ が ON， $\mathrm{a}_{1} ， \mathrm{a}_{2}$ が OFF の場合には負電圧が印加 される。また，同軸ケーブルに電圧が印加された状態でリ レーc を $400 \mathrm{~Hz}$ でスイッチングすることにより, 正負のパ

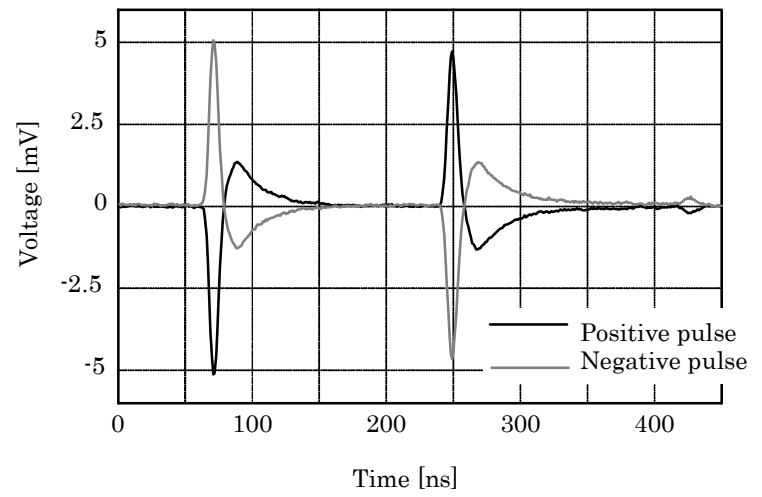

図 10 正負パルス電圧による出力信号

Fig. 10. Output signal wavefroms by the positive and negative pulse voltage.

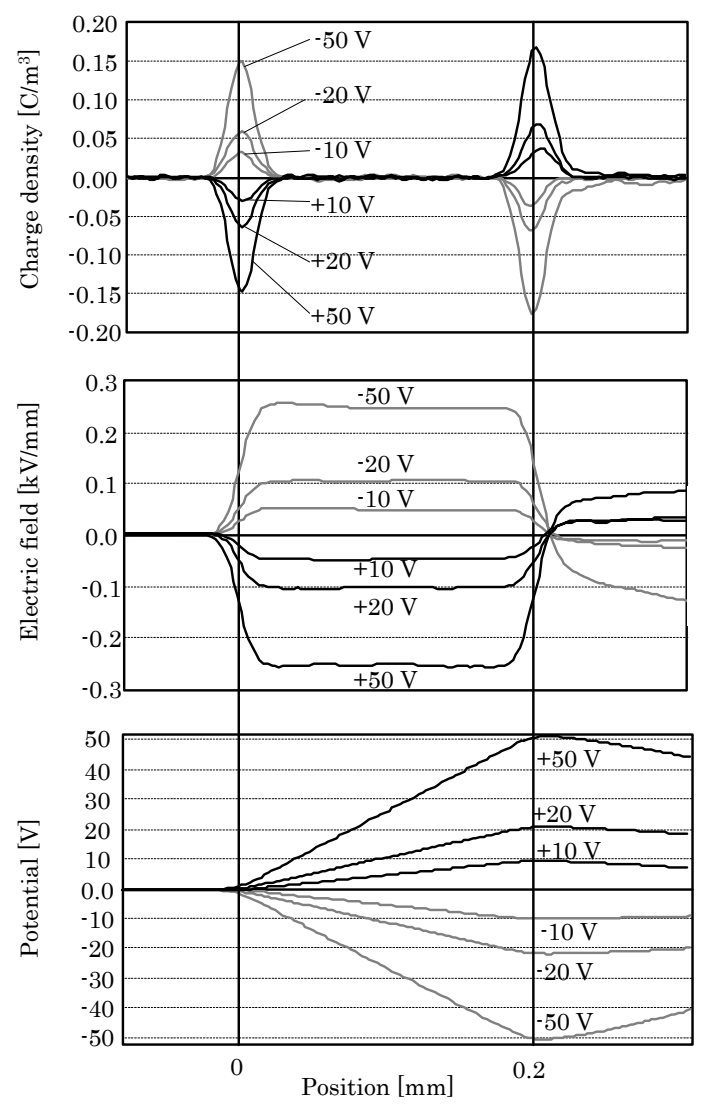

(b) Applied voltage : $\pm 50,20,10 \mathrm{~V}$

図 $110.2 \mathrm{~mm}$ 厚 PEN の電荷, 電界, 電位分布: 印加電圧 $(\mathrm{a}) \pm 500,250,100 \mathrm{~V},(\mathrm{~b}) \pm 50,20,10 \mathrm{~V}$

Fig. 11. Charge, electric field and potential distributions in dc biased 0.2mm-thick PEN : Baias voltage (a) $\pm 500,250,100 \mathrm{~V}$, (b) $\pm 50,20,10 \mathrm{~V}$. 
ルス電圧を出力している。今回開発した装置では 100 パル スごとにパルスの極性を反転している。信号取り込み，平 均化はそれぞれの極性で行った後, 差を計算することで信 号を得ている。極性反転などの一連の操作はコンピュータ 一で行われ，1 セットの処理に約 0.8 秒必要である。

図 8 にパルサーから出力された正負のパルス電圧波形を 示す。電圧極性によらず，パルス電圧の大きさ，形状は良 く一致している。

図 9 に作製した正負パルス電圧発生器を用いて, $0.5 \mathrm{~mm}$ 厚のポリメチルメタクリレイト (PMMA), 印加電圧 $0 \mathrm{~V} の$ 条件で, パルス電圧 $\pm 400 \mathrm{~V}$ を印加したときの圧電素子から の出力信号を示す。印加電圧は $0 \mathrm{~V}$ なので, 図 9 に示す圧電 素子から出力される信号は，(6)式の第 2 項, 印加パルス電 圧のみにより発生した圧力波である。（6)式からも分かるよ うにこのマックスウェル応力はパルス電界の 2 乗に比例す るので，パルス電圧の極性によらず同極性の信号が得られ るはずであり, 図 9 からもそれがわかる。次に同じ PMMA 試料に印加電圧 $+3 \mathrm{kV}$ の条件で，パルス電圧 $\pm 100 \mathrm{~V}$ を印加 したときの圧電素子からの出力信号を図 10 に示す。この測 定条件では，(6)式の第 2 項は第 1 項と比べると無視できる ほど小さいので, 出力信号は, 電極界面の誘導電荷の大き さに比例し, パルス電界の極性に依存した極性の出力信号 が観測された。出力信号の電圧極性は反転するが，パルス 電圧極性によらず，界面電荷に対する装置のインパルスレ スポンスは一致している。

図 11 に開発した高感度 PEA 装置を用いた微小電荷量の 測定結果を示す。(a) には, 図 4 と同様の実験条件 $(0.2 \mathrm{~mm}$ 厚の $\mathrm{PEN}$, パルス電圧 $\pm 400 \mathrm{~V}$, 印加電圧 $\pm 500,250,100 \mathrm{~V}$, 同期加算平均数 5000 回）で, 測定された電荷分布, 電界, 電位分布を示す。単一極性のパルス電圧を用いた従来の測 定では，印加電圧士250, $100 \mathrm{~V}$ の場合，測定誤差は $10 \%$ 以 上大きくなる。しかし, 正負パルス電圧を用いて誤差を除 去することにより, 電荷量から算出された電界, 電位分布 が印加電界, 電圧と誤差 10\%以内で一致したことからマッ クスウェル応力による誤差を除去することができたといえ る。更に(b)にはパルス電圧 $\pm 400 \mathrm{~V}$, 印加電圧を $\pm 50,20$, $10 \mathrm{~V}$ とし, 同期加算平均数 40000 回（約 5 分間）としたと きの結果を示す。十分な回数の平均化により, 電荷量から 算出された電界, 電位が印加電界, 電圧と $10 \%$ 以内で一致 し, $0.03 \sim 0.15 \mathrm{C} / \mathrm{m}^{3}$ といった微小電荷量が測定可能になっ た。

\section{5. まとめ}

正負パルス電圧を用いてマックスウェル応力により生じ る界面電荷の誤差を除去する方法を考案し, 従来より一桁 低い空間電荷密度の測定が可能な高感度 PEA 装置を開発し た。高感度 PEA 装置を用いて, PEN0.2mm, パルス電圧 $400 \mathrm{~V}$, 同期加算平均 40000 回の条件で印加電圧 $10 \mathrm{~V} \sim 50 \mathrm{~V}$ を印加し電荷量を測定した。その結果, 界面に発生する電 荷 $0.03 \sim 0.15 \mathrm{C} / \mathrm{m}^{3}$ の電荷量を誤差 $10 \%$ 以内で測定するこ
とに成功した。

正負 100 回ずつのパルスを発振して 1 組の同期加算平均 データを取得し演算するのに, 現在のパルサーでは 0.8 秒必 要である。これは機械的なリレーを用いているので, 電圧 極性の変更に時間が掛かるためである。現在, 数 $\mathrm{kHz}$ で動 作する半導体リレーが市販されているので, リレーをこの ようなものに変更すればより高速な測定が可能であると考 えられる。

(平成 16 年 7 月 1 日受付, 平成 17 年 10 月 14 日再受付)

\section{文献}

(1) T. Maeno, T. Futami, H. Kushibe, T. Takada, and C.M.Cooke : "Measurement of Spatial Charge Distribution in Thick Dielectrics Using the Pulsed Electroacuostic Methode", IEEE Trans. DEI, Vol.23, No. 3, p.433 (1988)

(2) T. Maeno, K.Fukunaga, Y. Tanaka, and T. Takada : "Signal Processing of High Resolution PEA Charge Measurement System" IEEJ Trans. FM, Vol.115, No.5, pp.405-410 (1995-5) (in Japanese)

前野 恭- 福永 香 - 田中康寛・高田達雄 :「高分解能 PEA 空間電 荷測定装置における信号処理」, 電学論 A, 115, 5, pp.405-410 (1995-5)

(3) Y. Murakami, H. Matsumura, N. Hozumi, M. Nagao, S. Mitsumoto, and M. Fukuma: "Space Charge Formation and Electric Breakdown with EVA Film at Room Temperature Region”, IEEJ Trans. FM, Vol.123, No.10, pp.1045-1050 (2003-10) (in Japanese)

村上義信・松村弘美・穂積直裕 - 長尾雅行 - 光本真一 ・ 福間題澄 : 「室温領域における EVA フィルムの空間電荷形成と絶緣破壊」, 電 学論 A, 123, 10, pp.1045-1050 (2003-10)

(4) G. Mazzanti, G. C. Montanari, and J. M. Alison : "A space-charge based method for the estimation of apparent mobility and trap depth as markers for insulation degradation-theoretical basis and experimental validation", IEEE Trans. DEI, Vol.8, No.2, pp.867-873 (2001)

(5) T. Maeno "Calibration of Pulsed Electroacoustic Method for Measuring Space Charge Distribution”, T.IEE Japan, Vol.119-A, No.8/9, pp.114-119 (1995)

（6） A. Ziel 著（瀧・飯島・田宮 訳）：雑音, 近代科学社（1961）

松井康 平 (学生員) 1978 年 5 月 29 日生まれ。 2002 年 3 月

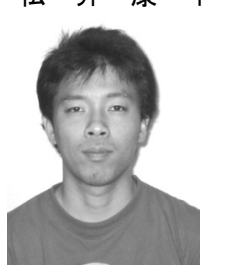
武蔵工業大学機械システム工学専攻修士課程修 了。同大学博士後期課程。主として誘電体中の空 間電荷分布測定に関する研究に従事。

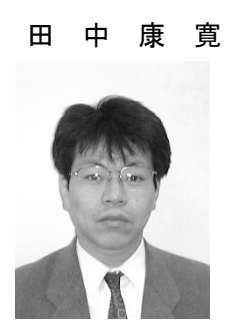

（正員） 1961 年 9 月 10 日生まれ。1991 年 3 月 早稲田大学大学院理工学研究科博士課程修了。 1990 年 4 月同大学助手属任。1992 年 4 月武蔵工 業大学機械工学科専任講師, 1998 年 4 月同大学 助教授。2004 年 4 月同教授着任。工学博士。 ‘ 1999 年 4 月 - ' 2000 年 3 月英国サザンプトン 大学客員研究員。主として有機高分子材料の高電 界特性, 特に空間電荷分布測定の研究に従事。 1990 年電気学会論文発表賞受賞。IEEE 会員。 
高 田 達 雄 （正員） 1939 年 8 月 8 日生まれ。1963 年 3 月

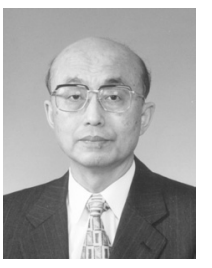
武蔵工業大学電気工学科卒業。 1966 年 3 月東北 大学大学院工学研究科電気及び通信工学専攻修 士課程修了。1967 年 4 月武蔵工業大学講師, 1974 年同助教授, 1986 年同教授, 現在に至る。工学 博士。1981 年 83 年米国 MIT 客員研究員。主と して高分子誘電体中の帯電現象と空間電荷分布 測定技術の研究に従事。1974，81，90 年電気学 会論文賞受賞。1996 年電気学会進歩賞受賞。1997 年静電気学会進 歩賞受賞。IEEE Fellow。

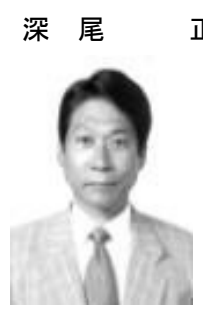

正（正員） 1940 年生。1969 年 3 月東京工業大学大 学院博士課程修了。同年 9 月同大学工学部助手, 1977 年 3 月同助教授, 1986 年 6 月同教授, 2001 年 3 月退官, 名誉教授。同年 4 月武蔵工業大学工 学部機械システム工学科教授, 現在に至る。工学 博士。半導体電力変換装置とその応用, 高速回転 機に関する研究に従事。IEEE Fellow。

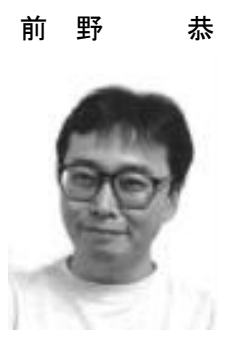

恭（正員） 1957 年 8 月 28 日生まれ。1989 年 3 月 武蔵工業大学大学院工学研究科電気工学専攻博 土課程修了。現在, 通信総合研究所電磁波計測 部門ライダーグループ所属。工学博士。主とし て誘電体中の空間電荷分布, 電界分布の計測お よびレーザー応用研究に従事。1999 年より武蔵 工業大学機械システム工学科客員助教授。1990 年電気学会論文賞, 1996 年電気学会進歩賞, 1997 年静電気学会進歩賞受賞。 